\title{
Formative e-Assessment for Moroccan Polyvalent Nurses Training: Effects and Challenges
}

\section{Case of the Higher Institute of Nursing and Health Techniques of Casablanca}

\author{
https://doi.org/10.3991/ijet.v15i14.13821 \\ Halima Lajane $\left.{ }^{(}\right)$, Rachid Gouifrane \\ Hassan II University of Casablanca, Morocco \\ halimalajane12@gmail.com \\ Rabia Qaisar \\ Higher Institute of Nursing and Health Techniques of Casablanca (ISPITS) \\ Hassan II University of Casablanca, Morocco \\ Fatim Zehra Noudmi \\ Higher Institute of Nursing and Health Techniques of Casablanca (ISPITS) \\ Said Lotfi, Ghizlane Chemsi, Mohamed Radid \\ Hassan II University of Casablanca. Morocco
}

\begin{abstract}
Formative e-assessment is an innovative teaching practice to enhance learning. However, teachers encounter multiple difficulties in integrating it. In this article, we present the results of an exploratory study conducted with nurses' teachers $(n=10)$ to identify the challenges that prevent the integration of technology in formative assessment. Moreover, we expose the results of a learning experience in order to measure the effect of formative e-assessment on teaching the course of surgical nursing care. Our population includes fifty-eight $(\mathrm{n}=$ 58) polyvalent student nurses, divided into two groups: an experimental group and a control group. Only the experimental group has been invited to respond to self-assessment quizzes posted online after the course sessions.

The positive effect on learning was demonstrated, after comparing the summative scores of the two groups (the p-value of the Mann-Whitney Test is less than 0.05). Also, the qualitative study has demonstrated challenges in ICT integration, absence of institutional directives recommending the use of ICT, required technical skills, diversity of tasks required of teachers, lack of material resources and absence of an institutional platform. The obtained results conclude that the formative assessment facilitated by ICT positively influences the students' summative scores. This conclusion should encourage and motivate teachers to integrate ICT into their formative assessment practices in order to better achieve the learning objectives. However, it seems necessary to involve the actors responsible for training nurses in order to support teachers in the pedagogical integration of ICT.
\end{abstract}


Keywords - Formative e-assessment, ICT integration, challenges, learning, summative scores

\section{Introduction}

Formative assessment is an assessment that guides and orients each learner in their training [1]. This evaluative practice can be either formal or informal; formal when teachers use instruments such as exercises, online tests, self-assessment forms, and questionnaires, and informal in the absence of tools based on class questions and group discussions [2]. For many years, this evaluative approach, in its formal form, has been practiced through 'paper-pencil' tests that the teacher corrects [3]. This form of formative assessment does not fully promote speed of feedback or the student's active involvement in the formative assessment process. Thus, the use of information and communication technologies for education (ICT) and the internet are presented as an alternative to traditional approaches of formative assessment; given the advantages, they present [4].

In their review of the literature on online formative assessment, Gikandi and al. (2011) [5] concluded that this digital approach promotes student's engagement and the development of a learning community. As for nursing education, several authors agree that digital assessments bring significant gains for both the teacher and the student. Needham and al. (2018) [6] underlined that the implementation of an evaluation tool on an online platform allowed overcoming the challenges inherent in the management of data evaluation on paper supports. As for Garrett and al. (2013) [7], the use of digital e-portfolios as a tool for evaluating the clinical skills of student nurses could offer teachers a better transparency and a better monitoring of students' progress. Hutton and al. (2010) [8] showed that an online assessment tool was used to assess student nurses' skills in calculating drug doses. They concluded that the tool could be used alongside the current assessments. Furthermore, the study by Campas and al. (2016) [9] has shown that students' participation in online tests has improved summative scores performance compared to the results of students assessed differently.

Although many studies have highlighted the multiple advantages of digital formative assessment, teachers sometimes face obstacles that constrain the integration of ICT in their work. In this regard, authors have identified a number of obstacles including the lack of training, lack of appropriate software and hardware, insufficient teacher time and lack of administrative assistance $[10,11,12,13]$.

In Morocco, besides the technical skills of teachers, there are problems related to the material resources that must be available to successfully integrate ICT $[14,15]$. In order to remedy these dysfunctions, Morocco has launched the national strategy for the generalization of information and communication technologies in education that aims at promoting the integration of ICT in education. The main points of this new strategy lie in the equipment and training guidelines.

In the field of nursing education, there is very little literature that has focused on the integration of ICT in the education system. A study by the author [16] concluded that the use of ICT by paramedical teachers is developed in the professional stage only. 
Furthermore, a recent study conducted in 2018 at the Higher Institute of Nurses and Health Techniques of Casablanca (ISPITS) demonstrated that paramedical teachers have never practiced a digital formative assessment, and that they generally conduct informal, non-instrumented formative assessments [17].

Therefore, this article discusses an issue that is part of a strategy to improve formative assessment practices in nursing education. Two main questions are, then, to be answered:

1. What would be the main obstacles encountered by paramedical teachers in practicing digital formative assessment?

2. What would be the effect of a digital formative assessment on the learning outcomes of student nurses?

In order to answer these questions, three objectives are outlined and are presented as follow:

1. To identify the obstacles that prevent the integration of technology in formative assessment by paramedical teachers

2. To experiment digital formative assessment within the polyvalent nurses training

3. To measure the effect of digital formative assessment on the learning outcomes of student nurses via their summative grades.

\section{$2 \quad$ Literature Review}

\subsection{Formative assessment and the contribution of ICT}

Formative assessment is a practice that allows students to obtain formative feedback on their learning difficulties, and shows the teachers the limits of their activities [18]. Moreover, research has shown the effectiveness of this approach in achieving learning objectives [1]. These studies have emphasized the use of this teaching practice and the benefits it brings to learning. The interest in this practice also encouraged research in different contexts, which has marked reflection on the use of digital technology in formative assessment [19]. In fact, digital formative assessment allows students to identify their strengths and weaknesses, to improve their understanding and revise their work, leading to a committed and self-regulated learning [20].

In addition, Vonderwell and al. (2007) [21] argue that digital technology reinforces educational differentiation through individualized monitoring of students and the use of statistics and histories. Furthermore, the integration of assessment into online courses is an opportunity for the learner to interact dynamically with the other participants, particularly the teachers and their peers [22]. In this same context, Gikandi and al. (2011) [5] add that online assessment allows the active involvement of the learner and promotes meaningful learning experiences.

As far as the teacher is concerned, the use of digital technology reduces workload and makes correction more effective [23]. It, also, facilitates and accelerates the transmission of constructive feedback to students whose presentation is immediate and 
simple [23]. Many authors have emphasized the importance of formative feedback, which is mainly used to improve student's learning and consolidate the teacher-learner relationship [24].

On the other hand, Chemsi's study (2019) [25] has confirmed the effect of online formative assessment on students' behavioral engagement and their involvement in conducting formative assessments. Also, Bahati's study (2019) [26] showed students' satisfaction with the online formative assessment strategies and with the feedback quality. For Mackey and al. (2009) [27], online assessment strategies allow learners to assess their progress and achievements.

In short, the analysis of publications focusing on digital formative assessments has made it possible to recognize its great educational potential. It, therefore, constitutes an innovative pedagogical strategy since it facilitates immediate formative feedback and the engagement of students in the learning process [5].

\subsection{The formative e-assessment}

With the evolution of the digital technology, high-level technological systems are dedicated to the formative assessment of learning. These systems allow the computerization of test data and generate better monitoring of learning results while guaranteeing traceability [28]. According to the same author, a multitude of computer-assisted assessment systems and tools are offered based on the user's needs and the skills targeted by the assessment such as, ItemBanker, TestWare-AnyWere, CQuest, FastTestPro, InQsit, CASTLE -Computer Assisted Teaching and LEarning, Interactive Question Server, WebQuiz, Moodle, OpenSurveyPilot, Questiontools, Hot Potatoes, Adaptex Assessment System, etc.

Audet (2011) [29] clarified that various tools can be used to make online formative evaluations such as automated questionnaires, electronic portfolios, educational games such as quizzes, blogs, wikis and micro blogs, audio and video conferencing and other tools. In addition, several educational structures are increasingly using platforms to manage online learning activities. A wide variety of learning platforms exists and offers multiple choices for assessment, with different levels of complexity [29].

\subsection{Obstacles to the integration of ICT by teachers}

Despite the various advantages and benefits of digital formative assessment, obstacles to the integration of technologies in the field of education need to be raised. The report published in 2004 by The British Educational Communications and Technology Agency (BECTA) [30], highlighted two main obstacles to the integration of ICT in education; personal obstacles such as lack of time and resistance to change, and institutional obstacles such as lack of training and resources. These same obstacles have also been cited by other authors [10, 11, 12, 13]. Indeed, according to Cotkas (2009) [11], the main obstacles to the integration of ICT in teacher training lie in the lack of training, and the lack of appropriate software and hardware.

Pelgrum (2001) [12] added other obstacles such as teacher time limitation, insufficiency of technical support, lack of supervision, lack of administrative assistance, 
connection problems, and lack of information. Tondeur (2010) [31] concluded that the school administration support remains important for the integration of ICT by teachers. Drent (2007) [10] identified the limited use of ICT in the curriculum as one of the factors influencing the integration of ICT in education.

In Morocco, El widadi (2013) [14] identified the main factors influencing the use of ICT by teachers, including the information gap felt by teachers, technical and pedagogical qualification and the availability of equipment. For Mastafi (2013) [15], the use of ICT in the Moroccan education system remains very limited as he identified five main obstacles, namely obstacles related to infrastructure, professional development, institutional policy, cultural and linguistic issues and finally problems of the Moroccan education system. From these reviews of obstacles, we retain three factors influencing the integration of ICT in education and consequently the integration of digital formative assessment, namely professional development opportunities, institutional policies related to the use of ICT, and the organization of teachers' work.

\section{$3 \quad$ Research Methodology}

\subsection{Participants}

The participants in the exploratory qualitative study are paramedical teachers from the ISPITS of Casablanca $(n=10)$. The experimental sample includes all second-year polyvalent student nurses of the initial training, enrolled in the professional bachelor cycle $(n=58)$ of the Higher Institute of Nursing and Health Techniques (ISPITS) in Casablanca. This training institute has eight courses, each of which has its specificities related to the courses offered. The choice of this sector is justified by the mastery of the specialty and by the large number of students

\subsection{Data collection methods}

In order to serve the objectives of our study, the methodological approach has two distinct sides. Overall, the qualitative aspect does not only try to identify the possible obstacles teachers face in the integration of ICT in the formative assessment, but also to support proposals adapted to the context of training.

The method used for the qualitative study was based on semi-directive individual interviews with ten teachers $(n=10)$. Interviews are conducted in ISPITS Casablanca, for a period of 30 minutes per interview. The interview included two large open-ended questions in order to identify as much information as possible on the concepts explored and to deduce a contextual model.

Question n 1: As far as you are concerned, what are the main constraints of conducting an online formative evaluation?

Question n 2: What are your proposals to adopt a formative evaluation system integrating the ICTs at the ISPITS level in Casablanca?

The quantitative aspect is intended to measure the effects of online formative assessment on the learning of student nurses through their summative grades. This study is of 
quasi-experimental type randomized into an experimental group and a control group. Before teaching the course, students are randomly assigned to one of two groups: the control group $(A, n=29)$ and the experimental group $(B, n=29)$. The experimental group will benefit, in addition to the informal formative continuous assessments, from the formal formative assessments posted online at the end of each course session. The control group will only benefit from the informal formative evaluations carried out during the course.

The experimental study aims to test the following research hypothesis: the experimental group made up of student nurses participating in online formative assessments will obtain a higher score on the summative test compared to the students from the control group. The module "surgical nursing care" is the subject chosen for specific teaching at the start of the second year of the training course for polyvalent nurses. The module aims to acquire basic knowledge facilitating the mastery and implementation of surgical nursing. The purpose of the formative assessment is, therefore, to assess if the basic knowledge in surgical nursing is mastered by the students who are to become health professionals. After studying the intended course, a summative test was carried out to assess the effect of the approach on the summative scores of the two groups of students.

Table 1. Experimental design

\begin{tabular}{lccl}
\hline \multicolumn{1}{c}{ Group } & $\begin{array}{c}\text { Independent } \\
\text { variable }\end{array}$ & $\begin{array}{c}\text { Dependent } \\
\text { variable }\end{array}$ & Test \\
\hline $\begin{array}{l}\text { Experimental } \\
\text { Control }\end{array}$ & Electronic test & Summative scores & $\begin{array}{l}\text { Score of final test after } \\
\text { studying the intended course }\end{array}$ \\
\hline
\end{tabular}

\subsection{The experimental study design}

In this work, the instructionaldesign of formative assessment followed the Theoretical Model of formative assessment by William and Thompson (2007) [32]. This model combines formative assessment into five key strategies. For each key strategy, the authors have defined online activities for the formative assessment (fig.1). Thus, self-assessment tests are designed from Chamilo platform (LMS), with educational content conformed to the description of class courses. They are simple or enriched MCQs, true or false exercises, choose from the drop-down list, images to comment on, short answers, etc. Each student in the experimental group connects via their mobile phones, answers the proposed quizzes questions and obtains at the end of the quizze a formative mark, while allowing self-correction.

Also, these online tests have been designed so that there is a self-correction with the transmission of formative feedback. Thus, for each incorrect answer, the student receives the correct one with a feedback comprising additional explanations around the question and is referred to links to enrich their knowledge and understanding. The questionnaires are validated through asking the teacher to take the test, to correct and validate it. 
Paper-Formative e-Assessment for Moroccan Polyvalent Nurses Training: Effects and Challenges...

\begin{tabular}{|c|c|c|c|}
\hline & Where the learner is going? & Where the learner is now? & How to get there? \\
\hline \multirow[b]{2}{*}{ Teacher } & $\begin{array}{l}\text { 1-Clarifying, sharing } \\
\text { learning intentions }\end{array}$ & $\begin{array}{l}\text { 2-Engineering effective discussions, tasks and } \\
\text { activities that elicit evidence of learning }\end{array}$ & $\begin{array}{l}\text { 3-Providing feedback that moves } \\
\text { learning forward }\end{array}$ \\
\hline & $\begin{array}{l}\text {-Introduction page on the Chamilo } \\
\text { Homepage, clarifying the teaching } \\
\text { objectives of the assessment } \\
\text { activities } \\
\text {-Navigation Instructions }\end{array}$ & $\begin{array}{l}\text {-Create evaluation tasks to track student progress: } \\
\text { Teacher develops self-assessment quizzes based } \\
\text { on learning objectives. } \\
\text { - Encourage students to use the discussion forum } \\
\text { and explain why the forum is used in relation to } \\
\text { the objectives of the assessment }\end{array}$ & $\begin{array}{l}\text {-Create self-assessment quizzes via } \\
\text { Chamilo platform with } \\
\text { automatic feedbak and the student is } \\
\text { returned to links to enrich his } \\
\text { understanding: videos, files, schema...ect }\end{array}$ \\
\hline \multirow[b]{2}{*}{ Learner } & $\begin{array}{l}\text { 1-Understanding } \\
\text { intentions }\end{array}$ & \multicolumn{2}{|c|}{$\begin{array}{l}\text { 4-Activating students as } \\
\text { owners of their own learning }\end{array}$} \\
\hline & & \multicolumn{2}{|c|}{ 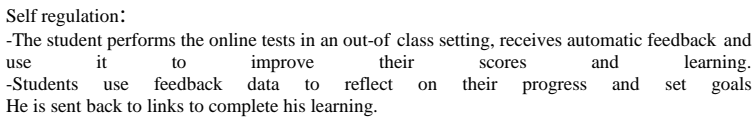 } \\
\hline \multirow{2}{*}{ Peer } & $\begin{array}{l}\text { 1-Understanding and , sharing } \\
\text { learning intentions }\end{array}$ & \multicolumn{2}{|c|}{ 5-Activating students as learning resources for one another } \\
\hline & & $\begin{array}{l}\text { - } \quad \text { Talk and discuss goals } \\
\text { - Discussion forum }\end{array}$ & \\
\hline
\end{tabular}

Fig. 1. Formative e-assessment process guided by the key aspects of formative assessment of William and Thompson (2007)
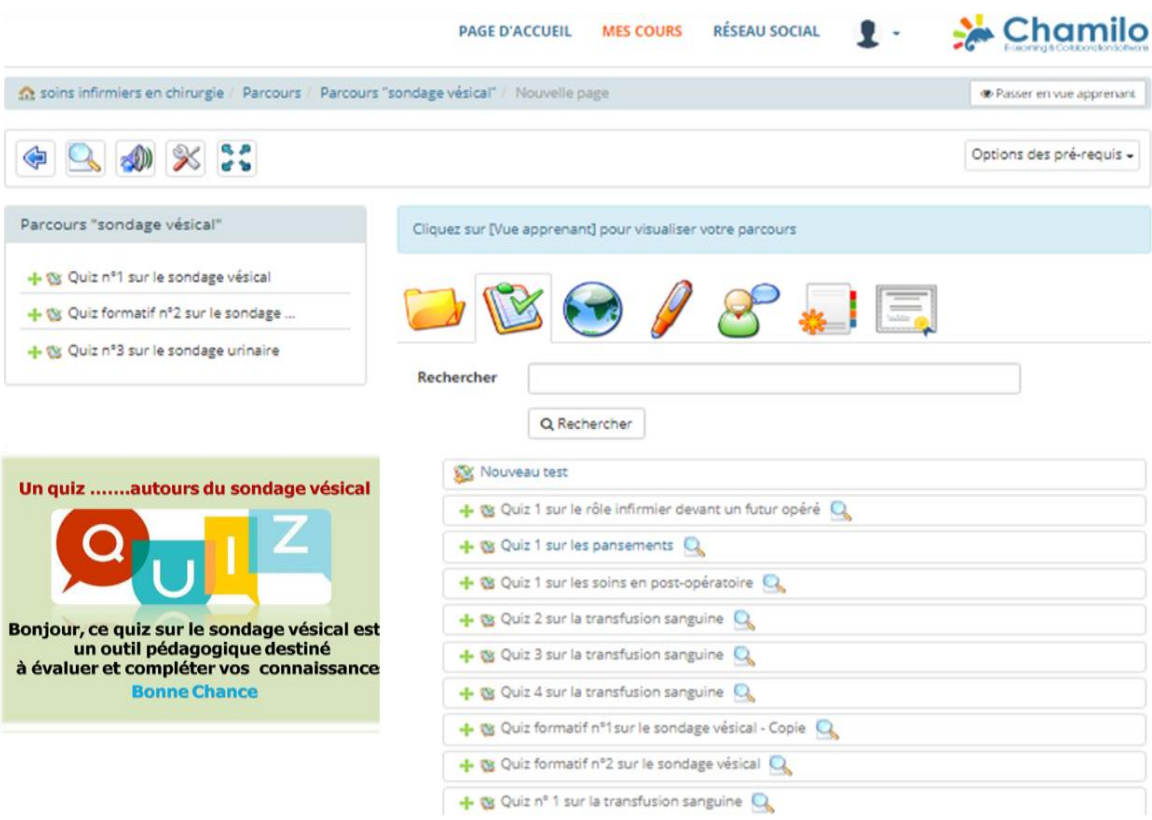

Fig. 2. Example of Quizzes on Chamilo plateform 


\subsection{Data analysis}

The data collected at the end of the experimental study are analysed using the SPSS computer software. The summative scores of the two groups of students are compared using Wilcoxon and Mann-Whitney Test. An inductive content analysis was used for the results from the exploratory qualitative study.

\section{$4 \quad$ Results}

\subsection{Results of the exploratory qualitative study}

Content analysis of the qualitative data allows meeting the major challenges inherent in adopting an evaluative approach based on ICT, and analysed according to the adopted theoretical model:

Institutional policies related to the use of ICT: The majority of teachers have substantiated the main organizational constraints which do not encourage conducting an online formative assessment, such as the absence of institutional directives recommending the use of ICT, lack of an institutional platform allowing teachers to share educational content with students, the absence of material resources such as computers and students access to a Wi-Fi network, also the insufficiency of documentation on the use of ICT in training. One teacher claimed that "the lack of an institutional platform does not encourage us, as teachers, to think about doing an online assessment. Also, the lack of computers and an accessible Wi-Fi network present themselves as constraints".

Opportunities for professional development: Teachers expressed their lack of training in innovative approaches integrating ICT in the field of teaching and specifically in the field of assessment. In fact, the training of paramedical teachers largely integrates the contributions of formative assessment whereas ICT is not sufficiently developed and knowledge of the software and digital tools used for online assessments lacks. "How can we be trained to do formative evaluation when we do not have enough knowledge on how to do an online assessment or how to have a platform? Are there any software or tools to help? ... " one of the teachers asked.

Teachers 'work organization: The participants' responses mainly refer to the workload and to the diversity of tasks required from teachers. Indeed, paramedical teachers are faced with many requirements in terms of study programs. At the same time, they are academic trainers and responsible for supervising clinical internships, adding to this the various tasks concerning the organization of internships, teaching planning activities and exam supervision. One of the most striking words of a teacher were, "even if we receive the necessary training and resources, workload will prevent us from doing effective online assessments, we do the teaching, supervision, monitoring and other tasks, sometimes we are overwhelmed". In addition to the encountered challenges, teachers added other factors such as the lack of local research on the contribution of ICT in nursing education, the doubt about the acceptability of this device by students and the motivation of teachers and students using ICT. 
Teachers, therefore, suggest "first of all, setting up an institutional platform where lessons and exercises can be posted", and indicate that "We must be trained in the field of ICT and how to make online quizzes ...", "(... ) rethink the role of students and make them more active through innovative ICT based strategies, "and" strengthen teacher training in the field of online formative assessment".

Henceforth, the implementation of these proposals remains essential for the adoption of this form of evaluation by teachers in the context of initial training of nurses at ISPITS in Casablanca.

Table 2. Themes and subthemes resulting from the content analysis of interviews $(\mathrm{N}=10)$

\begin{tabular}{|l|c|}
\hline \multicolumn{1}{|c|}{$\begin{array}{c}\text { Themes and subthemes } \\
\text { (Challenges for ICT integration) }\end{array}$} & $\begin{array}{c}\text { Number } \\
\text { of Statements } \\
(\mathrm{N}=10)\end{array}$ \\
\hline $\begin{array}{l}\text { Institutional policies related to the use of ICT } \\
-\quad \begin{array}{l}\text { Absence of institutional directives recommending the use of ICT } \\
\text { Lack of an institutional platform }\end{array}\end{array}$ & $\mathbf{3 0}$ \\
\hline $\begin{array}{l}\text { The absence of material resources such as computers } \\
\text { The insufficiency of documentation on the use of ICT in training } \\
-\quad \text { No Wi-Fi network available to students and teachers }\end{array}$ & $\mathbf{2 1}$ \\
\hline $\begin{array}{l}\text { Opportunities for professional development } \\
-\quad \begin{array}{l}\text { Lack of training in innovative approaches integrating ICT } \\
\text { Lack of knowledge of the software and digital tools used for online } \\
\text { Initial teacher training that does not integrate the use of technology }\end{array}\end{array}$ \\
\hline $\begin{array}{l}\text { Teachers 'work organization } \\
-\quad \text { The diversity of tasks required from teachers }\end{array}$ \\
\hline
\end{tabular}

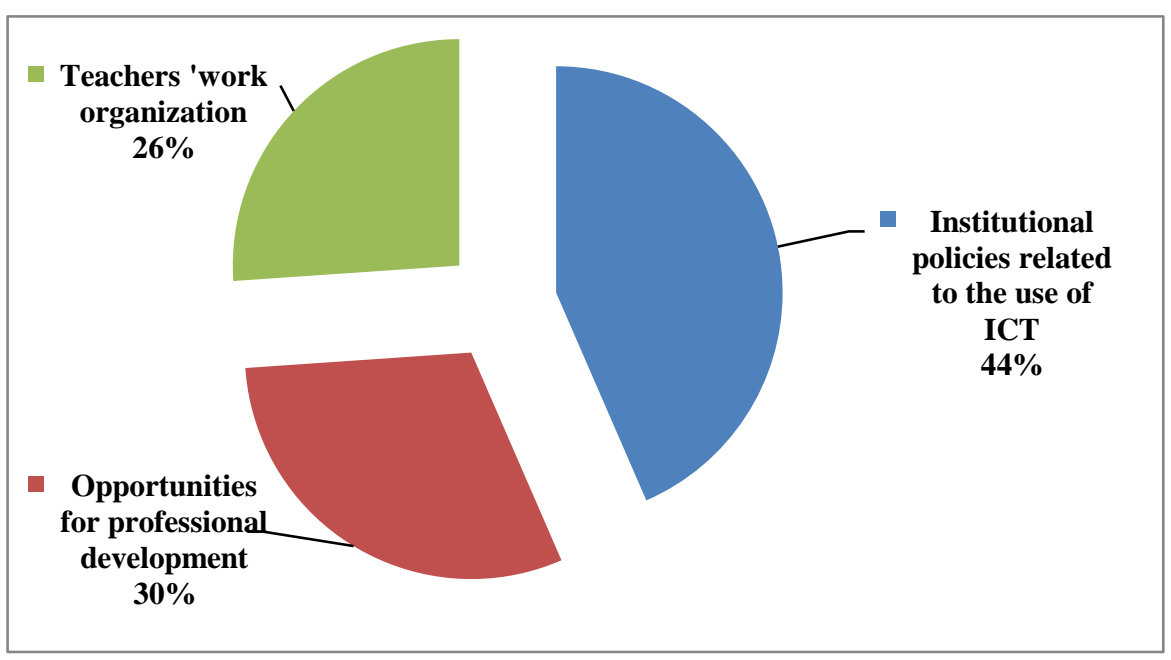

Fig. 3. Showing barriers affecting ICT integration for formative e- assessment 


\subsection{Results of the experimental study}

Concerning the experimental study, the positive effect of the digital formative evaluation on the learning of the subject has been demonstrated: the summative scores of the two groups of students are compared using Wilcoxon and Mann-Whitney Test.

\begin{tabular}{|c|c|c|c|c|c|c|}
\hline \multicolumn{5}{|c|}{ Note of matched samples } & \multicolumn{2}{|c|}{ Wilcoxon test } \\
\hline Groupe & Period & Average & $\mathrm{N}$ & Standard Deviation & $\mathrm{Z}$ & $\mathrm{P}$ \\
\hline Control & Pre-training & 2,448 & 29 & ,9291 & $-4,705^{b}$ & ,000 \\
\hline & Post -training & 13,897 & 29 & 3,4053 & & \\
\hline Experimental & Pre-training & 2,259 & 29 & 1,2220 & $-4,714^{b}$ & ,000 \\
\hline & Post -training & 18,517 & 29 & 1,4422 & & \\
\hline
\end{tabular}

Comparing the Pre-and Post-Training Notes between the 2 Groups:

a) Wilcoxon ranking test

b) Based on negative rows

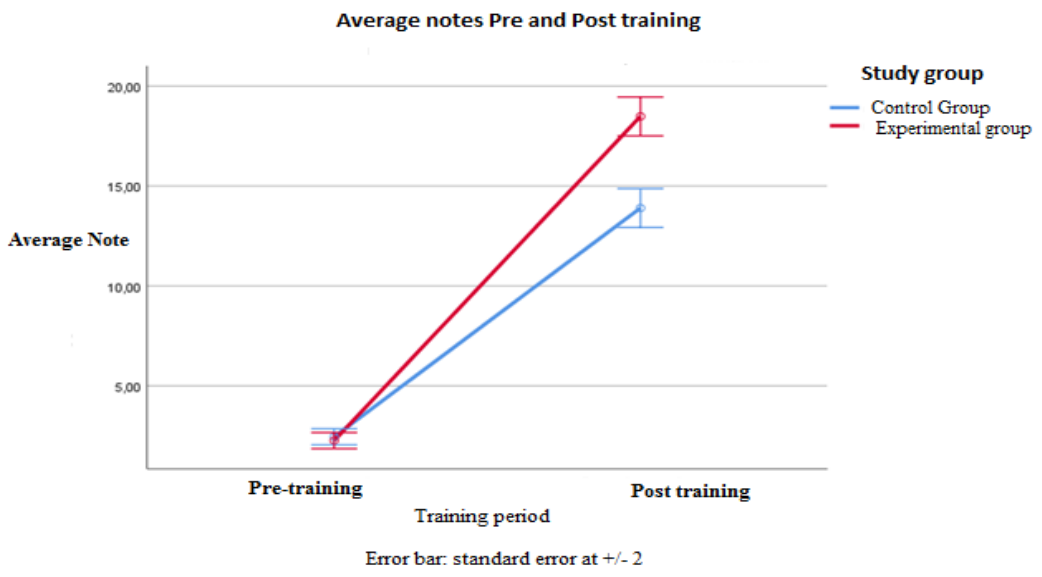

Comparisonof control and experimental group scores in pre- and post-training period:

\begin{tabular}{|c|c|c|c|c|c|c|}
\hline \multirow[b]{2}{*}{ Note } & \multirow[b]{2}{*}{ Period } & \multirow[b]{2}{*}{ Group } & \multirow{2}{*}{ Average } & \multirow{2}{*}{$\begin{array}{l}\text { Standard } \\
\text { deviation }\end{array}$} & \multicolumn{2}{|c|}{ Test U de Mann-Whitney } \\
\hline & & & & & $\mathrm{U}$ & $P$ \\
\hline \multirow[t]{2}{*}{ Pre-Test. Note } & \multirow[t]{2}{*}{ Pre training } & Control & 2,45 & ,93 & \multirow[t]{2}{*}{348,500} & \multirow[t]{2}{*}{, 255} \\
\hline & & Experimental & 2,26 & 1,22 & & \\
\hline \multirow[b]{2}{*}{ Post-Test.Note } & \multirow[b]{2}{*}{ Post training } & Control & 13,90 & 3,41 & \multirow[t]{2}{*}{92,000} & \multirow[t]{2}{*}{, 000} \\
\hline & & Experimental & 18,51 & 1,22 & & \\
\hline
\end{tabular}

Analysis of the data indicates that the average global score in the post -test for the experimental group is 18.51 points while the average global score for the control group is 13.90. The Mann-Whitney Test showing a significant difference between the two groups $(\mathrm{p}=0.00)$. In fact, the pre-test did not show a significant difference between the 
two groups, which is obvious because the students have not yet received any knowledge of the course. However, after the experiment, we found that the percentage change in post-test scores between the control and experimental groups was $33 \%$. It can, therefore, be said that participation in online formative assessments influences the summative marks obtained.

\section{Discussion}

This work is part of a reflection on innovative evaluation practices in the initial training of polyvalent nurses within the ISPITS of Casablanca. This reflection comes from a desire to enrich and improve this practice in its formal approach specifically by the use of the digital technology given the benefits it offers. However, the exploratory qualitative study can conclude that there are many constraints to the integration of ICT in nursing education in relation to formative evaluative practices. The raised constraints are generally related to teacher training, lack of resources and workload. Our results seem to perfectly match the conclusions drawn from the adopted theoretical model.

For the experimental study, it demonstrated that students who were involved in online formative assessment techniques performed better on summative evaluation compared to the control group. These results seem to fully corroborate those obtained from the study conducted by Campas and al. (2016) [9], which confirmed that participation in digital formative assessments had a positive impact on students' summative scores. Also, research by Fisher and al. (2011) [33] revealed that a formative evaluation approach based on the dissemination of comments after a first written evaluation made it possible to obtain higher marks in the tests, while facilitating students' learning. Our results are further reinforced by research findings in the nursing field. In this sense, Chen and Chuang (2012) [34] reported that the use of online tests constitutes tools to aid learning, even in the short term.

These types of results could bring new information to the teacher regarding their evaluative practices, and the approach should be considered beneficial for supporting the student nurses' learning. In fact, teachers judged this experience as useful since it offers them a better knowledge of their students' profiles and their learning difficulties and allows them to improve the module. Certainly, this study concluded that a formal online formative assessment process improves students' summative scores. However, would it be necessary for teachers to question deeper learning beyond summative grades? More specifically, to what extent could digital technology actually promote this type of learning? We take this as a perspective for future work.

\section{Limitations and Perspective of the Study}

Our research is limited to a small sample size. Therefore, the authors find it important to conduct more similar experiments in the framework of other theoretical courses in order to be able to draw a general conclusion. In addition, a questionnaire measuring the impact of the formative assessment on students' engagement has been distributed 
to students participating in the study, and the results will be presented in future publications.

\section{$7 \quad$ Ethical Considerations}

Before carrying out this study, ethical aspects were taken into consideration. Having the consent of the director of ISPITS Casablanca was necessary to be able to carry out this pilot experiment within this school. It should also be noted that participation in this study was voluntary, and the consent of the students was obtained after explaining the purpose and interest of the study. In addition, in order to guarantee equal learning opportunities for the students, the control group which did not benefit from the online assessment activities was able to carry them out at the end of the experiment. It is necessary to note that the summative test scores were not taken into account in the final evaluation of the module and were used only for the purposes of this research.

\section{Conclusion}

In this work, the authors sought to understand whether participation in formative online assessments has an effect on students' summative scores. The initial hypothesis was that the use of digital technology can facilitate and improve this evaluation process. The obtained results conclude that the formative evaluation facilitated by ICT positively influences the students' summative scores. This conclusion should encourage and motivate paramedical teachers to integrate ICT into their formative evaluation practices in order to better achieve the learning objectives.

However, the factors identified in the qualitative study are important for the pedagogical integration of ICT, despite the encouraging results of the experimental study. Ultimately, and in the light of all the results obtained, it seems necessary to involve the actors responsible for training nurses in order to support paramedical teachers in the pedagogical integration of ICT.

\section{Acknowledgements}

The authors would like to express their gratitude to all the teaching staff and the management of the ISPITS of Casablanca Settat for providing administrative and technical support.

\section{References}

[1] Black P, William D. Assessment and Classroom Learning. Assessment in Education: Principles, Policy \& Practice. mars 1998;5(1):7-74 https://doi.org/10.1080/09 $\underline{69595980050102}$ 
[2] Mottier Lopez, L. Evaluations formative et certificative des apprentissages. Enjeux pour l'enseignement. Bruxelles: De Boeck. 2015 [Formative and certification assessments of learning: challenges for the teaching profession]. https://doi.org/10.7202/1038472ar

[3] Allal, L., \& Mottier Lopez, L. Formative assessment of learning: A review of publications in French. In J. Looney (Ed.), Formative assessment: Improving learning in secondary classrooms 2005, ISBN-92-64-00739-3 @ OECD. https://doi.org/10.1787/9789264007413-sum$\underline{\mathrm{hu}}$

[4] Available at: http://www.oecd.org/education/ceri/34488354.pdf

[5] Peraya D. Aurélien FIÉVEZ (2017), L'intégration des TIC en contexte éducatif: modèles, réalités et enjeux . Préface de Marcel LEBRUN, Québec, Presses de l'Université du Québec. Communication Information médias théories pratiques [Internet]. 26 févr 2018 [cité 10 janv 2020] ;(vol. 35/1). Disponible sur: http://journals.openedition.org/ communication/7477. https://doi.org/10.2307/j.ctt1mf6z79

[6] [The integration of ICTs in educational contexts: models, realities and challenges]

[7] Gikandi JW, Morrow D, Davis NE. Online formative assessment in higher education: A review of the literature. Computers \& Education. déc 2011;57(4):2333-51 https://doi.org/10.1016/j.compedu.2011.06.004

[8] Needham, J., and al. The implementation of a nursing student clinical assessment tool onto an online platform: An evaluation by clinical facilitators and academic staff. Collegian (2018), https://doi.org/10.1016/j.colegn.2018.11.003

[9] Garrett BM, MacPhee M, Jackson C. Evaluation of an eportfolio for the assessment of clinical competence in a baccalaureate nursing program. Nurse Education Today. oct 2013;33(10):1207-13. http://doi.org/10.1016/j.nedt.2012.06.015

[10] Hutton M, Coben D, Hall C, Rowe D, Sabin M, Weeks K, et al. Numeracy for nursing, report of a pilot study to compare outcomes of two practical simulation tools - An online medication dosage assessment and practical assessment in the style of objective structured clinical examination. Nurse Education Today. oct 2010;30(7):608-14 https://doi.org/10.1016/j.nedt.2009.12.009

[11] Pla-Campas G, Arumí-Prat J, Senye-Mir AM, Ramírez E. Effect of Using Formative Assessment Techniques on Students' Grades. Procedia - Social and Behavioral Sciences. juill 2016; 228:190-5. https://doi.org/10.1016/j.sbspro.2016.07.028

[12] Drent M, Meelissen M. Which factors obstruct or stimulate teacher educators to use ICT innovatively? Computers \& Education. août 2008;51(1):187-99. https://doi.org/10.1016/j. compedu.2007.05.001

[13] Goktas, Y., Yildirim, S., \& Yildirim, Z. Main Barriers and Possible Enablers of ICTs Integration into Pre-service Teacher Education Programs. Educational Technology \& Society, 2009; 12 (1), 193-204. https://www.researchgate.net/publication/220374064

[14] Pelgrum WJ. Obstacles to the integration of ICT in education: results from a worldwide educational assessment. Computers \& Education. sept 2001;37(2):163-78. https://doi.org/10.1016/s0360-1315(01)00045-8

[15] Villeneuve, S., Karsenti, T. \& Collin, S. (2013). Facteurs influençant l'utilisation des technologies de l'information et de la communication chez les stagiaires en enseignement du secondaire. Éducation et francophonie, 41 (1), 30-44. https://doi.org/10.7202/1015058ar [Factors influencing the use of information and communication technologies among trainees in secondary education]

[16] El ouidadi, O, Lakdim,A, Essafi, K. Les Principaux facteurs influençant les usages des TICE chez des enseignants marocains. 2013;16. Laboratoire LADIPEC « Laboratoire de Didactique et des Innovations Pédagogiques et Curriculum » Université Sidi Mohamed Ben Abdellah. Faculté des Sciences Dhar Mahraz, B.P. 1796. Fès-Atlas. Maroc 
http://www.frantice.net/docannexe/fichier/737/5.Ouidadi.pdf[Main factors influencing ICT use among Moroccan teachers]. https://doi.org/10.21474/ijar01/6075

[17] Mastafi M. Intégration et usages des TIC dans le système éducatif marocain: attitudes des enseignants de l'enseignement primaire et secondaire [Internet]. http://www.adjectif.net/spip.2013 [cité 6 janv 2020]. http://www.adjectif.net/spip/spip.php?article228[Integration and uses of ICTs in the Moroccan education system: attitudes of primary and secondary school teachers]. https://doi.org/10.1787/888932868274

[18] Reguragui S, Raghay K, Janati-Idrissi R. Intégration des TIC dans les pratiques professionnelles et pédagogiques des enseignants: Cas de l'Institut Supérieur des Professions Infirmières et Techniques de Santé de Tétouan [ Integration of ICT in the professional and pedagogical practices of teachers: Case of the Higher Institute of Nursing Professions and Technicals of Health of Tetouan ]. 2017; 21(2):8, http://www.ijias.issr-journals.org/ https://doi.org/10.18356/ba2d655e-fr

[19] Lajane, h, Chemsi, R, Radid,M. La place de l'évaluation formative dans la formation initiale des infirmiers et des techniciens de santé : modalités de mise en œuvre et obstacles à la pratique. Actes de colloques ADMEE Suisse, 2019. [The place of formative assessment in the initial training of nurses and health technicians: modalities of implementation and barriers to practice]_http://wp.unil.ch/admee2019/files/2019/07/ActesADMEE2019-1.pdf. https://doi.org/10.1177/102538239700400208

[20] Nicol DJ, Macfarlane-Dick D. Formative assessment and self-regulated learning: a model and seven principles of good feedback practice. Stud High Educ. avr 2006;31(2):199-218. https://doi.org/10.1080/03075070600572090

[21] Endrizzi L, Rey O. L'évaluation au cœur des apprentissages. 2008;19. Dossier d'actualité de la VST, n 39, novembre. En ligne: <http://www.inrp.fr/vst/LettreVST/39-novembre2008.php>. [Assessment at the heart of learning]

[22] Wolsey, T. Efficacy of Instructor Feedback on Written Work in an Online Program. International Journal on E-Learning, 2008; 7(2), 311-329. Waynesville, NC USA: Association for the Advancement of Computing in Education (AACE). Retrieved April 7, 2020 from https://www.learntechlib.org/primary/p/23564/.

[23] Vonderwell S, Liang X, Alderman K. Asynchronous Discussions and Assessment in Online Learning. Journal of Research on Technology in Education. Mars 2007;39(3):309-28. https://doi.org/10.1080/15391523.2007.10782485

[24] Norbert Pachler, Harvey Mellar, Caroline Daly, Yishay Mor, Dylan Wiliam, et al. Scoping a vision for formative e-assessment: a project report for JISC. 2009; https://hal.archives-ouvertes.fr/hal-00591948

[25] Rey,O; Rey Feyfant A. Évaluer pour (mieux) faire apprendre. Dossier de veille de l'IFÉ $\bullet \mathrm{n}$ 94 • Septembre 2014; http://veille-et-analyses.ens-lyon.fr/DA-Veille /94-septembre-2014.pdf [ Assessing to (better) teach]

[26] Boud D. Assessment 2020: Seven propositions for assessment reform in higher education. 2010; Sydney: Australian Learning and Teaching Council https://www.uts.edu.au/sites /default/files/Assessment 2020_propositions_final.pdf

[27] Chemsi G, Sadiq M, Radid M, Talbi M. Formative E-Assessment and Behavioral Commitment of Students: Case of the Faculty of Science Ben M'sik. Int J Emerg Technol Learn. 27 juin 2019;14(12):4. https://doi.org/10.3991/ijet.v14i12.10389

[28] Bahati B, Fors U, Hansen P, Nouri J, Mukama E. Measuring Learner Satisfaction with Formative e-Assessment Strategies. Int J Emerg Technol Learn. 11 avr 2019;14(07):61. https://doi.org/10.3991/ijet.v14i07.9120 
[29] Mackey T, Derr D, O'Connor E. Cost-Effective Strategies for Developing Formative Assessments in Online Workplace Training. Int J Adv Corp Learn. 6 nov 2009;2(4):44-9. https://doi.org/10.3991/ijac.v2i4.992

[30] Blais J-G. Évaluation des apprentissages et technologies de l'information et de la communication: enjeux, applications et modèles de mesure. Québec: Presses de l'Université Laval; 2009. ISBN 978-2-7637-8711-4 [Assessment of Learning and Information and Communication Technologies: Issues, Applications and Measurement Models]. https://doi.org/10.7202/039865ar

[31] Audet L. Les pratiques et défis de l'évaluation en ligne.: 109. Document préparé pour le Réseau d'enseignement francophone à distance du Canada; 2011. http://archives.refad.ca/evaluation en ligne.pdf[The practices and challenges of online assessment]

[32] BECTA - British Educational Communications and Technology Agency, ICT Research. (2004). A review of the research literature on barriers to the uptake of ICT by teachers. BECTA, ICT Research. http://dera.ioe.ac.uk/1603/1/becta 2004_barrierstouptake_litrev.pdf. https://doi.org/10.1596/26090

[33] J. Tondeur, M. Cooper \& C.P. Newhouse, From ICT coordination to ICT integration: a longitudinal case study. Journal of Computer Assisted Learning (2010), 26, 296-306 https://doi.org/10.1111/j.1365-2729.2010.00351.

[34] Wiliam D, Thompson M. Integrating assessment with instruction: What will it take to make it work? In: Future of assessment: Shaping teaching and learning. 2008. p. 53-82. https://doi.org/10.4324/9781315086545-3

[35] Fisher R, Cavanagh J, Bowles A. Assisting transition to university: using assessment as a formative learning tool. Assessment \& Evaluation in Higher Education. Mars 2011;36(2):225-37; http://doi.org/10.1080/02602930903308241

[36] Chen H-Y, Chuang C-H. The learning effectiveness of nursing students using online testing as an assistant tool: A cluster randomized controlled trial. Nurse Educ Today. avr 2012;32(3):208-13. https://doi.org/10.1016/j.nedt.2011.03.004

\section{Authors}

Halima Lajane is a Ph.Dc in Educational Technology. She is a Nurse Teacher and the head of continuing education office at Ibn Rochd hospital of Casablanca, Morocco. She is a member of Association for the Development of Evaluation Methodologies In Education (ADMEE)-Section Morocco. She is a member of Laboratory of Physical Chemistry of Materials (LCPM) at Ben M'Sik Faculty of Sciences, Hassan II University of Casablanca, Morocco.

Rachid Gouifrane is a Ph.Dc in Educational Technology. He is a Nurse Teacher and the head of continuing education office at Ibn Rochd hospital of Casablanca, Morocco. He is a member of Association for the Development of Evaluation Methodologies in Education (ADMEE)-Section Morocco. He is a member of Laboratory of Physical Chemistry of Materials at Ben M'Sik Faculty of Sciences (LCPM), Hassan II University of Casablanca, Morocco.

Rabia Qaisar is a Ph.Dc in Educational Technology. She is a Nurse Teacher at Higher Institute of Nursing and Health Techniques of Casablanca. She is a member of the Multidisciplinary Laboratory in Sciences and Information Communication and Education Technology (LAPSTICE) at Ben M'Sik Faculty of Sciences, Hassan II 
University of Casablanca, Morocco.She is a member of Association for the Development of Evaluation Methodologies in Education (ADMEE)-Section Morocco.

Fatim Zehra Noudmi: She is a Nurse Teacher at Higher Institute of Nursing and Health Techniques (ISPITS) of Casablanca, branch: Nursing. She is the teacher responsible for the surgical nursing course.

Said Lotfi is a PhD in Education assessment measure. He is a member of Laboratory of Education and Training Sciences. Evaluation of Sport Sciences and Didactic of Physical Activity. He is a Professor at Higher Normal School (ENS), Hassan II University of Casablanca, BP 50069, Ghandi, Casablanca Morocco.

Ghizlane Chemsi: is a PhD in Educational Technology. She is a Professor at Faculty of Sciences Ben M'Sik, University Hassan II of Casablanca, Morocco, B.P 7955 Sidi Othmane. She operates in several fields of educational sciences: educational technologies and assessment, engineering of assessment. She is a Member of the Observatory of Research in Didactics and University Pedagogy (ORDIPU), Member of Association for the Development of Evaluation Methodologies in Education (ADMEE) - section Morocco and the Multidisciplinary Laboratory in Sciences and Information Communication and EducationTechnology (LAPSTICE).

Mohamed Radid is a PhD in Physical Chemistry. He is currently the Vice Dean of the Faculty of Sciences Ben M'Sik at Hassan II University, B.P 7955 Sidi Othmane, and Casablanca, Morocco since 2014. He is a Member of the Observatory of Research in Didactics and University Pedagogy (ORDIPU) and Member Board of Directors of Association for the Development of Evaluation Methodologies in Education (ADMEE) - Europe. He is an Expert in the fields of teaching and research on educational and technologies assessment, engineering of assessment, Chemistry Didactics, University Pedagogy.

Article submitted 2020-02-18. Resubmitted 2020-03-28. Final acceptance 2020-03-30. Final version published as submitted by the authors. 